Pol. J. Food Nutr. Sci., 2022, Vol. 72, No. 1, pp. 5-15

On-line ISSN: 2083-6007

Print ISSN: $1230-0322$

DOI: $10.31883 /$ pjfns/144223 http://journal.pan.olsztyn.pl

Original article

Section: Food Quality and Functionality

\title{
Characterisation of Selected Emulsion Phase Parameters in Milk, Cream and Buttermilk
}

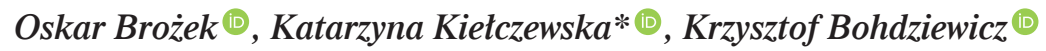 \\ Department of Dairy Science and Quality Management, Faculty of Food Sciences, \\ University of Warmia and Mazury in Olsztyn, Oczapowskiego Str. 7, 10-719 Olsztyn, Poland
}

Key words: milk products, size of fat globules, fatty acid profile, differential scanning calorimetry curves, differential scanning calorimetry parameters

Milk fat undergoes modification during butter production, which can alter its parameters and suitability for processing. The aim of this study was to compare selected milk fat parameters, including the size of milk fat globules, fatty acid profile and thermal properties, based on the thermal history of milk, cream and sweet buttermilk obtained during continuous churning in butter production. The size of milk fat globules was measured by the laser diffraction method; the fatty acid profile of milk fat was determined by gas chromatography; and the thermal properties of freeze-dried samples were determined by differential scanning calorimetry. The analysed products were arranged in the following descending order based on the size of milk fat globules, expressed by the Sauter mean diameter: cream > raw milk > buttermilk. Buttermilk was characterised by the greatest variations in the size of milk fat globules. A microscopic analysis revealed that an increase in fat content intensified the agglomeration of milk fat globules in cream relative to milk. Chains of milk fat globules were observed in buttermilk. Buttermilk was more abundant in monoenoic and polyenoic fatty acids than raw milk and cream. A thermal analysis demonstrated significant $(p \leq 0.05)$ differences in the parameters of fat crystallisation and melting peaks between raw milk, buttermilk and cream. The thermal history of the samples influenced the results. Cream was characterised by significantly greater changes in the melting and crystallisation enthalpy of milk fat and significantly higher peaks than milk and buttermilk.

\section{INTRODUCTION}

Many food products can be considered oil-in-water (o/w) or water-in-oil (w/o) emulsions. Dairy products such as milk, cream and buttermilk are examples of natural o/w emulsions in which the dispersed phase is fat in the form of globules. Milk fat globules comprise a lipid core surrounded by a stabilizing membrane with a thickness of $10-20 \mathrm{~nm}$. The membrane acts as an emulsifier and promotes the dispersion of fat globules in milk. The membrane also protects fat globules against flocculation, coalescence, oxidation and hydrolysis, which improves the processing suitability of milk fat [El-Loly, 2011; Singh \& Gallier, 2017; Smoczyński et al., 2012]. In their native form, milk fat globule membranes are complex structures with numerous components. The mass of the membrane accounts for 2-6\% of the total mass of fat globules, and membrane proteins and lipids represent more than $90 \%$ of its dry mass [Jukkola \& Rojas, 2017; Singh, 2006; Singh \& Gallier, 2017; Smoczyński et al., 2012]. Polar lipids, mainly phosphatidylcholine, phosphatidylethanolamine and sphingomyelin, and in smaller amounts - phosphatidylinositol, phosphatidylserine and lysophosphatidylcholine, make up 25\% of the milk fat globule membrane [Conway et al., 2014; Dewettinck et al., 2008; El-Loly, 2011; Singh, 2006; Smoczyński et al., 2012].
Processing operations in dairy plants, including butter production, can affect the parameters of emulsions and modify the composition and properties of milk fat globule membranes [Jukkola \& Rojas, 2017]. During churning, fragments of fat globule membranes are released into the hydrophilic phase of milk, which increases the content of polar lipids in the dry matter of buttermilk [Dewetinck et al., 2008; Lambert et al., 2016; Lopez et al., 2015].

Milk fat is characterised by a high content of palmitic acid which is a saturated fatty acid. Oleic acid is the predominant unsaturated fatty acid. The fatty acid composition of phospholipids differs from that of triacylglycerols [Jhanwar \& Ward, 2014]. Phospholipids contain mainly unsaturated fatty acids whose contents are higher in the membrane than in the lipid core of milk fat globules [Fauquant et al., 2005; Sanchez-Juanes et al., 2009]. Briard et al. [2003] demonstrated that the composition of fatty acids was influenced by the size of milk fat globules. Small fat globules contain more lauric, myristic, palmitic and palmitoleic acids than large fat globules. In turn, larger fat globules are more abundant in oleic and linoleic acid than fat globules with a small diameter. These differences can be attributed to a relatively higher content of membrane components in fat composed of smaller globules, and a smaller content of membrane

\footnotetext{
* Corresponding Author: 
components in fat composed of larger globules. According to Fauquant et al. [2005], the size of fat globules determines the fatty acid composition of the membrane and the lipid core of a fat globule, which is consistent with the previous findings of Briard et al. [2003].

The melting point of milk fat ranges from $-40^{\circ} \mathrm{C}$ to $40^{\circ} \mathrm{C}$, and crystallisation occurs between $20^{\circ} \mathrm{C}$ and $-20^{\circ} \mathrm{C}$. The melting and crystallisation of milk fat are influenced by the size of milk fat globules, the composition of the emulsion and the structure of triacylglycerols, including their fatty acid profile and crystal polymorphism. These parameters of the emulsion phase are reflected in differential scanning calorimetry (DSC) curves, including the number of peaks, peak temperature and overlapping peaks, which are also affected by scan rate (heating/cooling rate) and thermal history [Hokkanen et al., 2021, Michalski et al., 2004; Tomaszewska-Gras, 2013; Truong et al., 2014]. The DSC peaks do not represent the crystallisation or melting of individual fatty acids, but the entire milk fat mixture. Therefore, peak temperature is determined by several factors, including the overlap between peaks (mainly simultaneous phase transitions of different fatty acids), and triacylglycerol polymorphism [Tomaszewska-Gras, 2013]. In DSC analyses, fat crystallisation is usually represented by two exothermic peaks during cooling. Melting is visualised by three endothermic peaks corresponding to low- (LMPF), middle- (MMPF) and high-melting point fractions (HMPF). Truong et al. [2014] observed that the fatty acid profile contributes to differences in the crystallisation curves of anhydrous milk fat, and stearin (hard fraction with a higher content of saturated fatty acids) and olein fractions (soft fraction with a higher content of monounsaturated and polyunsaturated fatty acids). The cited authors also found that a decrease in crystallisation onset temperature $\left(\mathrm{T}_{\text {onser }}\right)$ and enthalpy change $(\Delta \mathrm{H})$ was associated with a decrease in the size of fat droplets. Similar relationships were reported for milk fat globules [Bugeat et al., 2011; Lopez et al., 2001, 2007].

The size of milk fat globules influences their fatty acid profile, which is partly associated with the content of fat globule membranes in the product. Processing operations during butter production, including milk centrifugation and churning, modify the fatty acid profile of skim milk, cream and buttermilk. The composition of fatty acids differs subject to their origin. Buttermilk contains fragments of milk fat globule membranes that are released during churning, which can induce changes in fatty acid composition regardless of the size of fat globules. The fatty acid profile of polar lipids in milk fat globule membranes derived from buttermilk differs from the fatty acid profile of lipids derived from whole milk [Jhanwar \& Ward, 2014; Singh \& Gallier, 2017]. Truong et al. [2014] observed that the crystallisation temperature of emulsified fats decreased with the decrease in droplet size.

Berton et al. [2012] analysed the digestion of native and homogenised milk fat globules in vitro and evaluated the benefits of replacing homogenisation with other fractioning methods based on the size of milk fat globules, including membrane filtration [Michalski et al., 2006] and centrifugation [Dhungana et al., 2017]. Therefore, the applicability of milk fat with differently sized milk fat globules and different fatty acid profiles should be analysed to maximise the functional and bioactive attributes of the end product. For example, the application of milk fat derived from buttermilk increases phospholipid levels and improves the health-promoting properties of dairy products containing buttermilk [Gassi et al., 2016; Hickey et al., 2017].

Differential scanning calorimetry is a technique that enables the identification of phase transitions, and the obtained results deliver new knowledge and can be effectively used in dairy practice. Thermal analyses investigate the effects of temperature on milk, cream and buttermilk, and the results can be used to select the optimal process parameters and to modify the production technology of dairy products. Sweet buttermilk has attracted considerable interest as a product that is abundant in milk fat globule membrane components. The thermal properties of buttermilk can be effectively harnessed in the process of developing new dairy products and new production technologies.

The comprehensive comparison of the emulsion phase parameters, such as the size of fat globules, fatty acid profile and thermal properties of milk, cream and sweet buttermilk is insufficient in the literature. The aim of this study was to select the parameters of phase transition peaks differentiating milk, cream and sweet buttermilk, and to determine the influence of thermal history on the characteristics of DSC curves, considering the significant importance of the size of fat globules and fatty acid profile on the milk fat phase transitions.

\section{MATERIALS AND METHODS}

\section{Materials}

The experimental material comprised pooled samples of cow's milk produced in the Bałdy Educational and Research Station of the University of Warmia and Mazury (UWM) in Olsztyn. Milk was cooled and transported in a refrigeration unit to the laboratory of the Faculty of Food Sciences of the UWM in Olsztyn. The raw milk, matured cream (obtained by centrifuging raw milk) and buttermilk (obtained by continuous churning of cream) were analysed. The experiment was performed in three replications.

\section{Proximate composition of milk, cream and buttermilk}

The dry matter content [AOAC International, method 990.20; 33.2.44, 2007], total nitrogen (TN) content (Kjeldahl method) [AOAC International, method 991.20; 33.2.11, 2007] and fat content (butyrometric method) [ISO 19662, 2018; ISO 19660, 2018] of the liquid samples of milk, cream and buttermilk were determined. Total protein content was calculated by multiplying the TN content of the samples by a conversion factor of 6.38 .

\section{Size of milk fat globules}

The size of milk fat globules was determined in liquid samples of milk, cream and buttermilk by the laser diffraction method in the Mastersizer 3000 particle size analyser and the Hydro EV sample dispersion unit (Malvern Instrument, Malvern, United Kingdom). The refractive index of milk was determined at 1.46, and the refractive index of Milli-Q deionised water (Millipore, Molsheim, France) was 1.33. 
The following parameters were determined: the diameter below which lies $10 \%$ of globules volume $\left(\mathrm{d}_{\mathrm{v}} 10\right)$; median diameter, $50 \%$ of the volume distribution is above, and $50 \%$ is below observed diameter $\left(\mathrm{d}_{\mathrm{v}} 50\right)$; the diameter below which lies $90 \%$ of globules volume ( $\left.\mathrm{d}_{\mathrm{v}} 90\right)$; uniformity of particles (SPAN), SPAN $=\left(d_{v} 90-d_{v} 10\right) / d_{v} 50$; a volume-surface mean diameter of fat globules, Sauter Mean Diameter $\left(\mathrm{d}_{32}\right), \mathrm{d}_{32}=\Sigma \mathrm{Sd}_{\mathrm{i}}{ }^{3} n_{\mathrm{i}} /$ $\mathrm{Sd}_{\mathrm{i}}{ }^{2} \mathrm{n}_{\mathrm{i}}$; a volume-weighted mean diameter, De Brouckere Mean Diameter $\left(\mathrm{d}_{43}\right), \mathrm{d}_{43}=\Sigma \mathrm{Sd}_{\mathrm{i}}^{4} \mathrm{n}_{\mathrm{i}} / \mathrm{Sd}_{\mathrm{i}}{ }^{3} \mathrm{n}_{\mathrm{i}}$, where $\mathrm{n}_{\mathrm{i}}$ is the number of particles with diameter $\mathrm{d}_{\mathrm{i}}$.

\section{Microscopic analysis}

The liquid samples of milk, cream and buttermilk were analysed under the Nikon Eclipse TieC 1 microscope (Nikon, Düsseldorf, Germany) at $60 \times$ magnification.

\section{Fatty acid profile}

Fat was extracted from milk, cream and buttermilk by the Rose-Gottlieb method [ISO, 2010]. Fatty acid esters were prepared according to a standard ISO 15884 method [ISO, 2002]. The fatty acid profile was determined by gas chromatography with a flame ionisation detector using the 7890 A Agilent Technologies system (Santa Clara, CA, USA). Separation was performed on the CP-Sil 88 column (100 m, $0.25 \mathrm{~mm}, 0.20 \mu \mathrm{m})$ (Agilent Technologies) with a temperature gradient of $60^{\circ} \mathrm{C}(1 \mathrm{~min})$ to $180^{\circ} \mathrm{C}$; time gradient of $5^{\circ} \mathrm{C} / \mathrm{min}$; injector temperature, $225^{\circ} \mathrm{C}$; detector temperature, $250^{\circ} \mathrm{C}$; carrier gas, helium; flow rate, $0.8 \mathrm{~mL} / \mathrm{min}$; split ratio, 1:100; sample volume, $1 \mu \mathrm{L}$; and liner, $0.4 \mathrm{~mm}$. The reference material was BCR-164 anhydrous milk fat (LGC Standards, Kiełpin, Poland). The proportions of saturated fatty acids (SFAs), monounsaturated fatty acids (MUFAs), polyunsaturated fatty acids (PUFAs), short-chain fatty acids (SCFAs), medium-chain fatty acids (MCFAs), long-chain fatty acids (LCFAs) and branched-chain fatty acids (BCFAs) were calculated. The proportions of SCFAs, MCFAs and LCFAs in total fatty acids were determined according to the method proposed by Jensen [2002]. The content of fatty acids was expressed in $\mathrm{g} / 100 \mathrm{~g}$ of total fatty acids in a product and in $\mathrm{g} / 100 \mathrm{~g}$ of the product. The following abbreviations were used in the description of fatty acid isomers: ai - anteiso, $\mathrm{i}$ - iso, $\mathrm{c}-$ cis, $\mathrm{t}$-trans.

\section{Freeze drying}

Milk, cream and buttermilk samples were freeze-dried in the Alpha 1-2 LD plus freeze-dryer (Martin Christ Gefriertrocknungsanlagen $\mathrm{GmbH}$, Osterode am Harz, Germany) at a pressure of 0.34 mbar and a temperature of $-32^{\circ} \mathrm{C}$.

\section{Analysis of freeze-dried samples}

Water activity $\left(\mathrm{a}_{\mathrm{w}}\right.$ ) of freeze-dried milk, cream and buttermilk was determined using the AquaLab 4TEV analyser (Meter Group AG, München, Germany). The analysis was carried out at a temperature of $25^{\circ} \mathrm{C}$. Water activity was measured with an accuracy of \pm 0.003 , and temperature was measured with an accuracy of $\pm 0.3^{\circ} \mathrm{C}$. The dry matter, fat and protein contents of freeze-dried samples were determined with the NIRS ${ }^{\mathrm{Tm}}$ DS2500 analyser (FOSS, Hilleroed, Denmark).

\section{Differential scanning calorimetry}

Freeze-dried milk, cream and buttermilk $(10 \pm 1 \mathrm{mg})$ were weighed on the Mettler Toledo XS205 Dual Range analytical balance (Mettler Toledo, Columbus, OH, USA), placed in airtight aluminium pans, and subjected to a thermal analysis with the use of the DSC Q10 instrument with a refrigerated cooling system (TA Instruments, New Castle, DE, USA). The cell was purged with dry nitrogen at $50 \mathrm{~mL} / \mathrm{min}$ and calibrated for baseline in an empty oven and for temperature using standard pure indium. An empty sealed aluminium pan was used as a reference in every test. Samples were cooled or heated at a rate of $10^{\circ} \mathrm{C} / \mathrm{min}$ and were held for $1 \mathrm{~min}$ at the endset temperature after each stage. They were analysed in triplicate in a DSC sequence composed of two cycles. Cycle I involved the following stages: 1) sample cooling from $30^{\circ} \mathrm{C}$ to $-40^{\circ} \mathrm{C}$; 2) sample heating from $-40^{\circ} \mathrm{C}$ to $95^{\circ} \mathrm{C}$. Cycle II commenced immediately after cycle I and involved sample cooling from $95^{\circ} \mathrm{C}$ to $-40^{\circ} \mathrm{C}$ and sample heating from $-40^{\circ} \mathrm{C}$ to $95^{\circ} \mathrm{C}$ in the following sequence: 1) cooling, 2) heating, 3) cooling, 4) heating, 5) cooling, 6) heating. Cycle II was applied to determine the effect of a sample's thermal history on the DSC curve, and to calculate the parameters of phase transition peaks. The results of the DSC analysis were processed using the Universal Analysis 2000 programme (TA Instruments). The following parameters of the identified phase transition peaks were determined: peak temperature $\left(\mathrm{T}_{\max } ;{ }^{\circ} \mathrm{C}\right.$; determined as the peak maximum), phase transition onset temperature $\left(\mathrm{T}_{\text {onset }} ;{ }^{\circ} \mathrm{C}\right.$; defined by the intersection of a line tangent to the steepest section of the leading edge and the baseline of the thermogram), peak width at half height $\left(\Delta \mathrm{T}_{1 / 2} ;{ }^{\circ} \mathrm{C}\right.$; temperature range of the transition as peak width at half height), enthalpy change $(\Delta \mathrm{H} ; \mathrm{J} / \mathrm{g}$; determined as the area limited by the curve, i.e. the peak and the baseline), peak height at maximum $\left(\mathrm{P}_{\text {height }} ; \mathrm{W} / \mathrm{g}\right.$; determined as the heat flow range limited by $\mathrm{T}_{\max }$ and $\mathrm{P}_{\mathrm{s}}$ ), peak onset temperature $\left(\mathrm{P}_{\mathrm{s}} ;{ }^{\circ} \mathrm{C}\right.$; a point where a peak is formed $)$ and peak endset temperature $\left(\mathrm{P}_{\mathrm{e}} ;{ }^{\circ} \mathrm{C}\right.$; a point where a peak ends).

\section{Statistical analysis}

The results were analysed by one-way ANOVA, and the significance of differences between means was determined in Duncan's test at $p \leq 0.05$. The percentage content of individual fatty acids in total fatty acids in different samples was subjected to principal component analysis (PCA). Data were processed statistically in StatSoft Inc. Statistica v. 13.1 software (Tulsa, OK, USA).

\section{RESULTS AND DISCUSSION}

\section{Proximate composition of raw milk, cream and buttermilk}

Raw milk contained $13.34 \pm 0.17 \mathrm{~g} / 100 \mathrm{~g}$ dry matter, $3.99 \pm 0.05 \mathrm{~g} / 100 \mathrm{~g}$ fat and $3.21 \pm 0.03 \mathrm{~g} / 100 \mathrm{~g}$ protein. Cream contained $53.59 \pm 4.40 \mathrm{~g} / 100 \mathrm{~g}$ dry matter, $46.38 \pm 2.55 \mathrm{~g} / 100 \mathrm{~g}$ fat and $2.77 \pm 0.11 \mathrm{~g} / 100 \mathrm{~g}$ protein. The content of dry matter, fat and protein in buttermilk was determined at $9.02 \pm 0.60 \mathrm{~g} / 100 \mathrm{~g}$, $0.56 \pm 0.01 \mathrm{~g} / 100 \mathrm{~g}$ and $3.02 \pm 0.08 \mathrm{~g} / 100 \mathrm{~g}$, respectively. The composition of milk, cream and buttermilk was similar to that described by other authors [Vanderghem et al., 2010]. 
TABLE 1. Size of fat globules in milk, cream and buttermilk.

\begin{tabular}{l|c|c|c|c|ccc}
\hline Product & $\mathrm{d}_{\mathrm{v}} 10(\mu \mathrm{m})$ & $\mathrm{d}_{\mathrm{v}} 50(\mu \mathrm{m})$ & $\mathrm{d}_{\mathrm{v}} 90(\mu \mathrm{m})$ & SPAN & $\mathrm{d}_{43}(\mu \mathrm{m})$ & $\mathrm{d}_{32}(\mu \mathrm{m})$ \\
\hline Milk & $0.56 \pm 0.01^{\mathrm{b}}$ & $3.69 \pm 0.18^{\mathrm{a}}$ & $7.75 \pm 0.05$ & $1.95 \pm 0.09^{\mathrm{b}}$ & $3.89 \pm 0.18$ & $1.70 \pm 0.02^{\mathrm{b}}$ \\
Cream & $0.93 \pm 0.08^{\mathrm{a}}$ & $3.87 \pm 0.19^{\mathrm{a}}$ & $8.35 \pm 0.55$ & $1.92 \pm 0.17^{\mathrm{b}}$ & $5.15 \pm 0.85$ & $2.22 \pm 0.10^{\mathrm{a}}$ \\
Buttermilk & $0.38 \pm 0.01^{\mathrm{c}}$ & $1.72 \pm 0.06^{\mathrm{b}}$ & $8.55 \pm 2.31$ & $4.74 \pm 1.22^{\mathrm{a}}$ & $5.42 \pm 1.25$ & $0.97 \pm 0.03^{\mathrm{c}}$ \\
\hline
\end{tabular}

The presented values are means \pm standard deviations $(n=3)$. Values with different superscripts $(a-c)$ in columns differ significantly at $p \leq 0.05$. $d, 10-$ diameter below which lies $10 \%$ of globules volume; $d_{v} 50$ - diameter below which lies $50 \%$ of globules volume; $d_{v} 90$ - diameter below which lies $90 \%$ of globules volume; SPAN - uniformity of particles; $\mathrm{d}_{32}$ - volume-surface mean diameter of fat globules; $\mathrm{d}_{43}$ - volume-weighted mean diameter.

\section{Size of milk fat globules}

The size of fat globules was determined in the samples of liquid milk, cream and buttercream. The products were arranged in the following order based on the decreasing diameter of the fat globules $\left(\mathrm{d}_{\mathrm{v}} 10\right)$ and the Sauter mean diameter $\left(\mathrm{d}_{32}\right)$ : cream $>$ raw milk $>$ buttermilk $(p \leq 0.05)$ (Table 1$)$. The values of $\mathrm{d}_{\mathrm{v}} 50$ did not differ significantly between milk and cream $(p>0.05)$, but they were significantly higher than in buttermilk $(p \leq 0.05)$. Buttermilk contained large fat globules or aggregates characterised by high values of $d_{v} 90$ and $d_{43}$. The size of fat globules was comparable in buttermilk and cream, but greater variations in $\mathrm{d}_{\mathrm{v}} 90$ and $\mathrm{d}_{43}$ were noted in buttermilk. Due to high standard deviation values, no significant differences in $d_{v} 90$ or $d_{43}$ values were found between the analysed samples $(p>0.05)$. Buttermilk was characterised by the highest values of SPAN $(p \leq 0.05)$ denoting the size distribution of fat globules in the sample (Table 1). The microscopic analysis revealed the presence of fat globule agglomerates in cream and chains of very small fat globules in buttermilk (Figure 1).

\section{Fatty acid profile}

The fatty acid profiles of fats extracted from milk, cream and buttermilk are shown in Table 2. The percentage content of individual fatty acids in the examined samples demonstrated that their fatty acid composition was characteristic of milk fat and similar to these reported in the literature [Briard et al., 2003; Fauquant et al., 2005]. In our study, the milk, cream and buttermilk fatty acid profiles differed significantly $(p \leq 0.05)$ in the content of C6:0, C12:0, C15:0 ai, C14:1, C16:0, C16:1, C17:0, C18:0, C18:1 $\Sigma \mathrm{t}$,

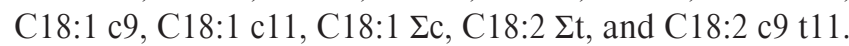
The percentage content of most of the above fatty acids was highest in buttermilk and lowest in milk. The only exceptions were C6:0, C16:0 and C18:0 whose proportions were highest in milk and lowest in buttermilk. The percentage content of $\mathrm{C} 12: 0$ and $\mathrm{C} 16: 1$ was highest in buttermilk and lowest in cream, whereas the content of C17:0 was highest in cream and lowest in milk. Milk and cream were characterised by lower proportions of C10:0, C10:1, C13:0 ai, C13:0, C14:0, C15:0, C18:1 c12 and C18:2 than buttermilk. In turn, buttermilk was less abundant in $\mathrm{C} 4: 0$ than the remaining products.

The variations in the fatty acid composition of the compared products could be attributed to differences in the fatty acid profile of phospholipids in buttermilk and milk. Buttermilk phospholipids have a lower content of C16:0 and a higher content of C18:0 and PUFAs that are found in larger quantities in membranes than inside milk fat globules [Fauquant et al., 2005; Garczewska-Murzyn et al., 2021; Jhanwar \& Ward, 2014]. The churning process induces a greater increase in phospholipid levels in buttermilk than in cream. Churning also increases the content of $\mathrm{C} 18: 1$ and $\mathrm{C} 18: 2$ in buttermilk relative to cream, and decreases the content of $\mathrm{C} 16: 0$ in buttermilk phospholipids relative to cream phospholipids [Hokkanen et al., 2021].

The potential relationship between the proportions of the analysed fatty acids and product type (milk, cream and buttermilk) was determined by PCA. The first two principal components (PC1 and PC2), presented in Figure 2, explained $92.45 \%$ of the total variance in input data. The first principal component (PC1) explained $71.81 \%$ of the variance in input data. A large positive score $(0.60)$ was observed for buttermilk in the first principal direction, on the opposite side of the PC1 axis relative to milk and cream. The score for cream was very small at 0.18 , whereas milk had
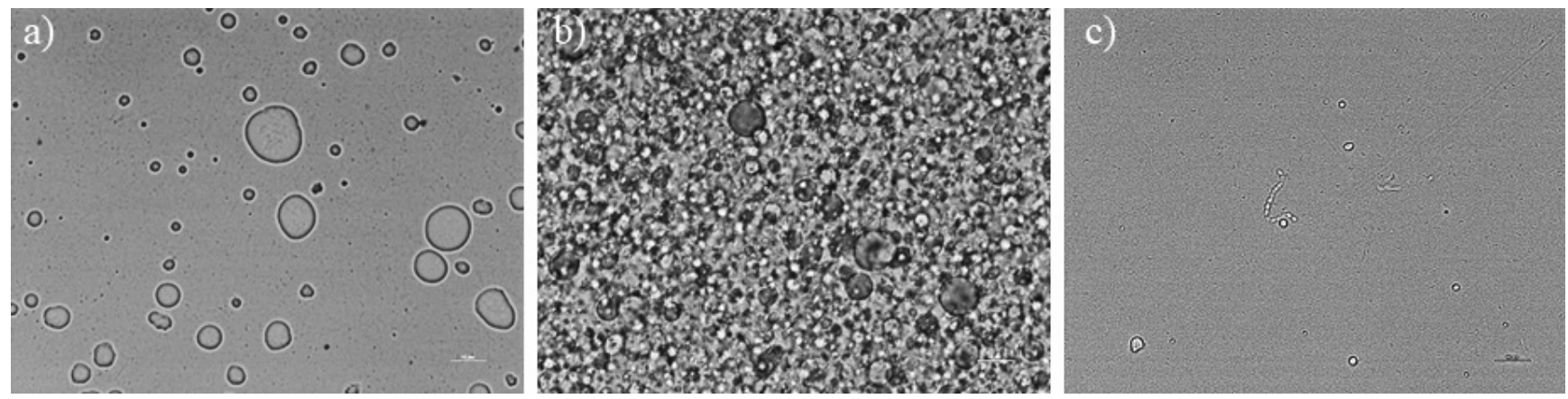

FIGURE 1. Microstructure of milk (a), cream (b) and buttermilk (c), $60 \times$ magnification. 
a larger score of 0.42 . Therefore, in milk and buttermilk, product type was highly related with the scalar projections for PC1. At the same time, the larger the loading for a given variable (fatty acid) relative to $\mathrm{PC} 1$, the greater the influence of product type (milk and buttermilk) on the percentage content of a given fatty acid. The points representing individual fatty acids and the sum of fatty acids of a given type were clustered in two groups at the opposite ends of the PC1 axis. The cluster on the left side of the plot grouped fatty acids with negative loadings in the range of -0.99 to -0.79 relative to the scalar projections for PC1. In this group, fatty acids were arranged in the following descending order based on the absolute value of the loadings relative to $\mathrm{PC} 1$ : $\mathrm{C} 16: 0 \mathrm{i}$, C14:0 i, C16:0, C4:0, C6:0 and C18:0. The second group on the right side of the $\mathrm{PC} 1$ axis contained fatty acids with very large loadings in the range of 0.77 to 0.99 . These fatty acids were arranged in the following ascending order based on the values of the loadings relative to PC1: C18:2 $\mathrm{\Sigma t}$, C18:1 c9, C15:0 i, C10:0, C12:0, C18:1 इc, C13:0 ai, C14:0, C13:0, C10:1, C18:1 c12, C18:2, C15:0, C18:1 c11, C18:1 ¿t, $\mathrm{C} 15: 0$ ai, $\mathrm{C} 14: 1$ and $\mathrm{C} 18: 2$ c9 $\mathrm{t} 11$. The second principal component (PC2) explained $20.37 \%$ of the variance in input data. Cream had a score of 0.29 , and it was represented by a point at the top of the plot. Milk had a negative loading of -0.22 , and it was represented by a point in the bottom part of the plot. Therefore, in milk and cream, the relationship between the proportions of fatty acids and product type was stronger in relation to the scalar projections for PC2 than PC1. The larger the loading for a given variable (fatty acid) relative to $\mathrm{PC} 2$, the greater the influence of product type (milk and cream) on the percentage content of a given fatty acid. In relation to $\mathrm{PC} 2$, very large loadings were observed for $\mathrm{C} 17: 0(0.94)$ at the top of the plot and C8:0 (-0.83) in the bottom part of the plot.

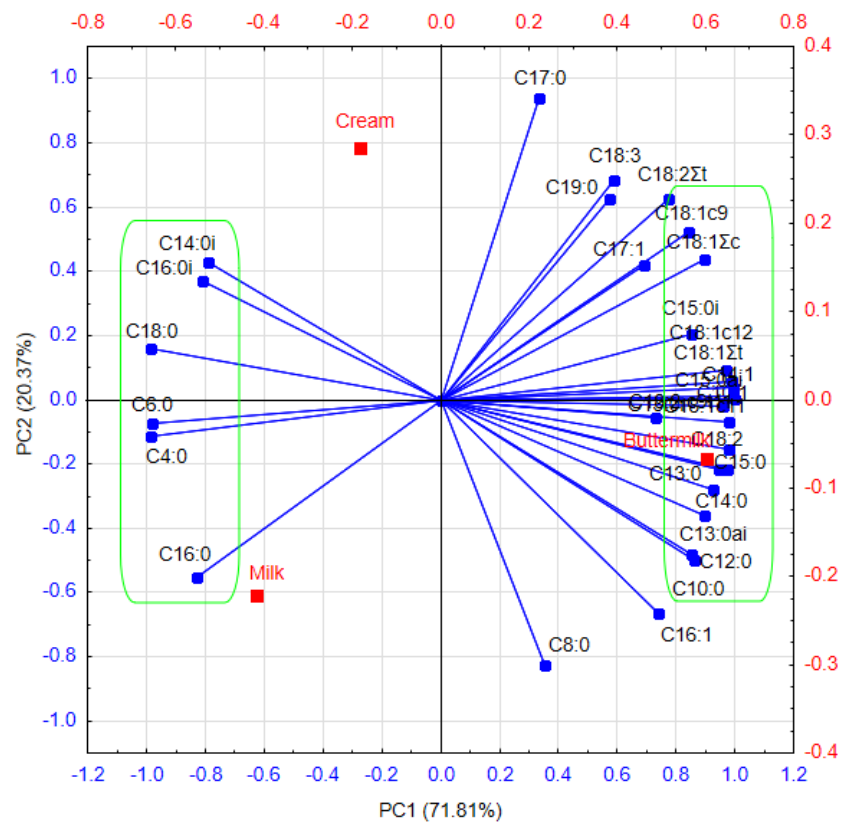

FIGURE 2. Principal component analysis (PCA) biplot of the milk, cream and buttermilk and relative content of their fatty acid to principal component 1 (PC1) and principal component 2 (PC2).
TABLE 2. Relative content of fatty acids of milk, cream and buttermilk (g/100 g total fatty acids).

\begin{tabular}{|c|c|c|c|}
\hline Fatty acid & Milk & Cream & Buttermilk \\
\hline C4:0 & $2.67 \pm 0.05^{\mathrm{a}}$ & $2.60 \pm 0.01^{\mathrm{a}}$ & $2.44 \pm 0.01^{b}$ \\
\hline C6:0 & $1.80 \pm 0.00^{\mathrm{a}}$ & $1.78 \pm 0.00^{\mathrm{b}}$ & $1.72 \pm 0.01^{\mathrm{c}}$ \\
\hline C8:0 & $1.11 \pm 0.01$ & $1.10 \pm 0.00$ & $1.11 \pm 0.01$ \\
\hline $\mathrm{C} 10: 0$ & $2.60 \pm 0.02^{\mathrm{b}}$ & $2.56 \pm 0.00^{\mathrm{b}}$ & $2.69 \pm 0.02^{\mathrm{a}}$ \\
\hline C10:1 & $0.25 \pm 0.00^{\mathrm{b}}$ & $0.26 \pm 0.00^{\mathrm{b}}$ & $0.27 \pm 0.00^{\mathrm{a}}$ \\
\hline $\mathrm{C} 12: 0$ & $3.12 \pm 0.00^{\mathrm{b}}$ & $3.06 \pm 0.00^{c}$ & $3.27 \pm 0.02^{\mathrm{a}}$ \\
\hline $\mathrm{C} 13: 0 \mathrm{i}$ & $0.07 \pm 0.00$ & $0.07 \pm 0.00$ & $0.07 \pm 0.00$ \\
\hline $\mathrm{C} 13: 0$ ai & $0.08 \pm 0.00^{\mathrm{b}}$ & $0.08 \pm 0.00^{\mathrm{b}}$ & $0.09 \pm 0.00^{\mathrm{a}}$ \\
\hline $\mathrm{C} 13: 0$ & $0.09 \pm 0.00^{\mathrm{b}}$ & $0.09 \pm 0.00^{\mathrm{b}}$ & $0.10 \pm 0.00^{\mathrm{a}}$ \\
\hline $\mathrm{C} 14: 0 \mathrm{i}$ & $0.12 \pm 0.00$ & $0.13 \pm 0.00$ & $0.12 \pm 0.00$ \\
\hline C14:0 & $11.07 \pm 0.02^{\mathrm{b}}$ & $11.06 \pm 0.00^{\mathrm{b}}$ & $11.20 \pm 0.03^{\mathrm{a}}$ \\
\hline $\mathrm{C} 15: 0 \mathrm{i}$ & $0.23 \pm 0.00^{\mathrm{b}}$ & $0.23 \pm 0.00^{\mathrm{ab}}$ & $0.24 \pm 0.00^{\mathrm{a}}$ \\
\hline C15:0 ai & $0.38 \pm 0.00^{c}$ & $0.41 \pm 0.00^{\mathrm{b}}$ & $0.47 \pm 0.00^{\mathrm{a}}$ \\
\hline C14:1 & $0.89 \pm 0.00^{c}$ & $0.91 \pm 0.00^{\mathrm{b}}$ & $1.01 \pm 0.01^{\mathrm{a}}$ \\
\hline C15:0 & $1.02 \pm 0.00^{\mathrm{b}}$ & $1.03 \pm 0.00^{\mathrm{b}}$ & $1.11 \pm 0.01^{\mathrm{a}}$ \\
\hline $\mathrm{C} 16: 0 \mathrm{i}$ & $0.29 \pm 0.00$ & $0.30 \pm 0.00$ & $0.28 \pm 0.00$ \\
\hline C16:0 & $32.84 \pm 0.09^{\mathrm{a}}$ & $31.80 \pm 0.01^{\mathrm{b}}$ & $31.48 \pm 0.06^{c}$ \\
\hline C16:1 & $1.51 \pm 0.01^{\mathrm{b}}$ & $1.47 \pm 0.01^{\mathrm{c}}$ & $1.55 \pm 0.00^{\mathrm{a}}$ \\
\hline $\mathrm{C} 17: 0$ & $0.40 \pm 0.00^{c}$ & $0.55 \pm 0.00^{\mathrm{a}}$ & $0.49 \pm 0.00^{\mathrm{b}}$ \\
\hline $\mathrm{C} 17: 1$ & $0.28 \pm 0.10$ & $0.37 \pm 0.00$ & $0.40 \pm 0.01$ \\
\hline C18:0 & $12.66 \pm 0.04^{\mathrm{a}}$ & $12.54 \pm 0.00^{\mathrm{b}}$ & $10.93 \pm 0.00^{c}$ \\
\hline $\mathrm{C} 18: 1 \Sigma \mathrm{t}$ & $1.57 \pm 0.03^{\mathrm{c}}$ & $1.68 \pm 0.04^{b}$ & $1.95 \pm 0.02^{\mathrm{a}}$ \\
\hline C18:1 c9 & $22.03 \pm 0.14^{\mathrm{c}}$ & $22.76 \pm 0.01^{\mathrm{b}}$ & $23.03 \pm 0.03^{\mathrm{a}}$ \\
\hline C18:1 c11 & $0.55 \pm 0.01^{\mathrm{c}}$ & $0.57 \pm 0.01^{\mathrm{b}}$ & $0.71 \pm 0.03^{\mathrm{a}}$ \\
\hline C18:1 c12 & $0.19 \pm 0.01^{b}$ & $0.21 \pm 0.00^{\mathrm{b}}$ & $0.25 \pm 0.01^{\mathrm{a}}$ \\
\hline $\mathrm{C} 18: 1 \Sigma \mathrm{c}^{1}$ & $22.77 \pm 0.13^{c}$ & $23.54 \pm 0.00^{\mathrm{b}}$ & $23.99 \pm 0.06^{\mathrm{a}}$ \\
\hline C19:0 & $0.28 \pm 0.01$ & $0.30 \pm 0.01$ & $0.30 \pm 0.00$ \\
\hline $\mathrm{C} 18: 2 \Sigma \mathrm{t}^{2}$ & $0.00 \pm 0.00^{c}$ & $0.14 \pm 0.01^{\mathrm{b}}$ & $0.17 \pm 0.00^{\mathrm{a}}$ \\
\hline C18:2 & $1.19 \pm 0.00^{\mathrm{b}}$ & $1.19 \pm 0.00^{\mathrm{b}}$ & $1.64 \pm 0.00^{\mathrm{a}}$ \\
\hline $\mathrm{C} 18: 3$ & $0.31 \pm 0.01^{\mathrm{b}}$ & $0.35 \pm 0.00^{\mathrm{a}}$ & $0.34 \pm 0.00^{\mathrm{ab}}$ \\
\hline $\mathrm{C} 18: 2 \mathrm{c} 9 \mathrm{t} 11$ & $0.38 \pm 0.00^{c}$ & $0.42 \pm 0.00^{\mathrm{b}}$ & $0.55 \pm 0.00^{\mathrm{a}}$ \\
\hline SFAs & $70.85 \pm 0.19^{a}$ & $69.68 \pm 0.03^{\mathrm{b}}$ & $68.13 \pm 0.09^{c}$ \\
\hline MUFAs & $27.26 \pm 0.19^{c}$ & $28.22 \pm 0.04^{\mathrm{b}}$ & $29.18 \pm 0.10^{\mathrm{a}}$ \\
\hline PUFAs & $1.88 \pm 0.01^{\mathrm{c}}$ & $2.10 \pm 0.01^{\mathrm{b}}$ & $2.69 \pm 0.00^{\mathrm{a}}$ \\
\hline SCFAs & $5.58 \pm 0.05^{\mathrm{a}}$ & $5.47 \pm 0.02^{\mathrm{b}}$ & $5.28 \pm 0.01^{\mathrm{c}}$ \\
\hline MCFAs & $54.57 \pm 0.10^{\mathrm{a}}$ & $53.45 \pm 0.02^{\mathrm{c}}$ & $53.96 \pm 0.09^{\mathrm{b}}$ \\
\hline LCFAs & $39.84 \pm 0.15^{\mathrm{b}}$ & $41.08 \pm 0.03^{\mathrm{a}}$ & $40.76 \pm 0.10^{\mathrm{a}}$ \\
\hline BSFAs & $1.17 \pm 0.01^{\mathrm{c}}$ & $1.21 \pm 0.00^{\mathrm{b}}$ & $1.28 \pm 0.00^{\mathrm{a}}$ \\
\hline
\end{tabular}

The presented values are means \pm standard deviations $(n=3)$. Values with different superscripts $(\mathrm{a}-\mathrm{c})$ in rows differ significantly at $p \leq 0.05$. n.d. - not detected; i - iso; ai - anteiso; c - cis; $\mathrm{t}$ - trans; SFAs - saturated fatty acids; MUFAs - monounsaturated fatty acids; PUFAs - polyunsaturated fatty acids; SCFAs - short-chain fatty acids, (C4-C8); MCFAs - medium-chain fatty acids, (C10-C16); LCFAs - long-chain fatty acids, (C17-C19); BSFAs - branched-chain fatty acids (C13:0 i, C13:0 ai, C14:0 i, C15:0 i, C15:0 ai, C16:0 i).

${ }^{1} \mathrm{C} 18: 1 \Sigma \mathrm{c}(\mathrm{c} 9, \mathrm{c} 11, \mathrm{c} 12)$.

${ }^{2} \mathrm{C} 18: 2 \Sigma \mathrm{t}$ (t9 c12, t11 c15, c9 t12, c9 t13). 
A comparison of the fatty acid groups located on opposite sides of the PC1 axis with the results of Duncan's test demonstrated that the proportions of these fatty acids (excluding C16:0 and C14:0 with loadings of 0.79 and -0.81 , respectively) were significantly $(p \leq 0.05)$ affected by product type. It can be assumed that the proportions of the remaining fatty acids also differed between the examined products (milk, cream and buttermilk).

The share of the main fatty acid groups, i.e. SFAs, MUFAs, PUFAs, SCFAs, MCFAs and BCFAs, in the total fatty acids differed significantly $(p \leq 0.05)$ between the analysed products (Table 2). Whole milk fat was most abundant in SFAs and least abundant in MUFAs, PUFAs and BCFAs. The proportion of SFAs was lowest, whereas the proportions of MUFAs, PUFAs and BCFAs were highest in buttermilk fat. In terms of the length of the fatty acid chain, MCFAs (mostly C16:0 and C14:0) were the predominant fatty acids. The content of MCFAs was lowest in cream fat and highest in milk fat. Buttermilk was least abundant in SCFAs relative to the remaining products. The content of LCFAs was highest in cream, lower in buttermilk, and lowest in milk. The LCFA values in cream and buttermilk fat formed a homogeneous group $(p>0.05)$ and differed significantly $(p \leq 0.05)$ from the values noted in milk. A similar content of MCFAs and LCFAs was reported by Jensen [2002]. The content of fatty acids per $100 \mathrm{~g}$ of the analysed product was approximately 15 times higher in cream than in buttermilk, and approximately 3 times higher in cream than in milk (Table 3 ).

\section{Differential scanning calorimetry}

DSC involved freeze-dried samples of milk, cream and buttermilk because the presence of water could lead to the formation of unclear peaks, in particular lipid phase transition peaks. During DSC analysis, the phase transition peaks of water can overlap with the peaks of the remaining milk components, which could prevent the identification of differences between the DSC curves of milk, cream and buttermilk. Water was removed from the samples by freeze-drying which is the least invasive dehydration technique with minimum effects on milk components [Pugliese et al., 2019].

Freeze-dried samples of buttermilk, milk and cream were characterised by water activity $\left(\mathrm{a}_{\mathrm{w}}\right)$ of $0.05-0.08$, dry matter content of $97.83 \pm 0.47 \mathrm{~g} / 100 \mathrm{~g}, 97.73 \pm 0.69 \mathrm{~g} / 100 \mathrm{~g}$ and $97.89 \pm 0.24 \mathrm{~g} / 100 \mathrm{~g}$; fat content of $5.70 \pm 0.17 \mathrm{~g} / 100 \mathrm{~g}$, $29.64 \pm 0.33 \mathrm{~g} / 100 \mathrm{~g}$ and $84.37 \pm 0.30 \mathrm{~g} / 100 \mathrm{~g}$; and protein content of $34.72 \pm 0.12 \mathrm{~g} / 100 \mathrm{~g}, 24.79 \pm 0.25 \mathrm{~g} / 100 \mathrm{~g}$ and $5.08 \pm 0.20 \mathrm{~g} / 100 \mathrm{~g}$, respectively.

Differential scanning calorimetry supported the identification of exothermic (Figure 3) and endothermic (Figure 4) peaks that occurred in all samples and differed between the analysed products. Exothermic peaks were noted during cooling, and they were identified as: A - peaks that occurred in all samples within a temperature range of around $11^{\circ} \mathrm{C}$ to around $-40^{\circ} \mathrm{C}$; $\mathrm{B}$ - peaks that were not clearly separated from peaks $\mathrm{A}$ and were observed in milk and cream within a temperature range of around $15^{\circ} \mathrm{C}$ to around $11^{\circ} \mathrm{C} ; \mathrm{C}$ - peak noted only in cream within a temperature range of around $20-22^{\circ} \mathrm{C}$ to around $15^{\circ} \mathrm{C}$. Peaks (A-C) denoting the crystallisation of the entire milk fat were not completely separated
TABLE 3. Fatty acid content of milk, cream and buttermilk (g/100 g of the product)

\begin{tabular}{lccc}
\hline Fatty acids & Milk & Cream & Buttermilk \\
\hline SFAs & $21.00 \pm 0.23^{\mathrm{b}}$ & $58.79 \pm 0.21^{\mathrm{a}}$ & $3.88 \pm 0.12^{\mathrm{c}}$ \\
MUFAs & $8.08 \pm 0.09^{\mathrm{b}}$ & $23.81 \pm 0.08^{\mathrm{a}}$ & $1.66 \pm 0.05^{\mathrm{c}}$ \\
PUFAs & $0.56 \pm 0.01^{\mathrm{b}}$ & $1.77 \pm 0.01^{\mathrm{a}}$ & $0.15 \pm 0.01^{\mathrm{c}}$ \\
SCFAs & $1.65 \pm 0.02^{\mathrm{b}}$ & $4.62 \pm 0.02^{\mathrm{a}}$ & $0.30 \pm 0.01^{\mathrm{c}}$ \\
MCFAs & $16.17 \pm 0.18^{\mathrm{b}}$ & $45.10 \pm 0.16^{\mathrm{a}}$ & $3.08 \pm 0.09^{\mathrm{c}}$ \\
LCFAs & $11.81 \pm 0.13^{\mathrm{b}}$ & $34.66 \pm 0.12^{\mathrm{a}}$ & $2.32 \pm 0.07^{\mathrm{c}}$ \\
BSFAs & $0.35 \pm 0.01^{\mathrm{b}}$ & $1.02 \pm 0.01^{\mathrm{a}}$ & $0.07 \pm 0.01^{\mathrm{c}}$ \\
\hline
\end{tabular}

The presented values are means \pm standard deviations $(n=3)$. Values with different superscripts $(\mathrm{a}-\mathrm{c}$ ) in rows differ significantly at $p \leq 0.05$. SFAs - saturated fatty acids; MUFAs - monounsaturated fatty acids; PUFAs - polyunsaturated fatty acids; SCFAs - short-chain fatty acids, (C4-C8); MCFAs - medium-chain fatty acids, (C10-C16); LCFAs - long-chain fatty acids, (C17-C19); BSFAs - branched-chain fatty acids (C13:0 i, C13:0 ai, C14:0 i, C15:0 i, C15:0 ai, C16:0 i).

at a cooling rate of $10^{\circ} \mathrm{C} / \mathrm{min}$. Milk fat was crystallised within a temperature range of $20^{\circ} \mathrm{C}$ to $-40^{\circ} \mathrm{C}$, but clear zones denoting the crystallisation of selected milk fat fractions were also observed. The first zone ranged from $20^{\circ} \mathrm{C}$ to $15^{\circ} \mathrm{C}$ (peak $\mathrm{C}$ ), and the second zone ranged from $10^{\circ} \mathrm{C}$ to $-40^{\circ} \mathrm{C}$ (peak A). These peaks were separated by a zone where the crystallisation of selected milk fat fractions was accompanied by less pronounced thermal effects (peak B). The partial overlap between peaks A and B resulted from similar phase transition characteristics of milk fat components [Tomaszewska-Gras, 2013].

The peaks on the DSC curves of milk, cream and buttermilk in the present study (Figure 3), had similar characteristics to those reported by Truong et al. [2014]. A review of the literature indicates that exothermic peaks (A-C) were associated with crystallisation [Hokkanen et al., 2021; Michalski et al., 2004; Tomaszewska-Gras, 2013; Truong et al., 2014]. Therefore, exothermic peaks A were probably associated with the proportions of MUFAs and PUFAs (mostly C18:1), whereas peaks B and C were influenced by the percentage content of SFAs (mostly C14:0, C16:0 and C18:0).

Endothermic peaks associated with milk fat melting were observed in the DSC curves of all samples (Figure 4) during heating within a temperature range of $-40^{\circ} \mathrm{C}$ to $95^{\circ} \mathrm{C}$. The first peak (D) did not have a clear onset temperature, and its endset temperature was determined at $18-24^{\circ} \mathrm{C}$. Peak D was associated with LMPF and MMPF that were not clearly separated (they were separated at a temperature of around $14^{\circ} \mathrm{C}$ in the DSC curves of cream and milk). The second peak (E) began at approximately $18-24^{\circ} \mathrm{C}$ and ended at $34-42^{\circ} \mathrm{C}$, and it was identified as HMPF.

In a study by Szulc et al. [2016], endothermic melting peaks in whole milk powder were identified in the temperature range of $-10^{\circ} \mathrm{C}$ to $50^{\circ} \mathrm{C}$. Endothermic peaks $\mathrm{D}$ and $\mathrm{E}$ associated with milk fat melting were reported by Hokkanen et al. [2021] and Michalski et al. [2004]. In the DSC curves of milk, cream and buttermilk, peak D representing the overlap between LMPF and MMPF was highly related with the scan rate. 

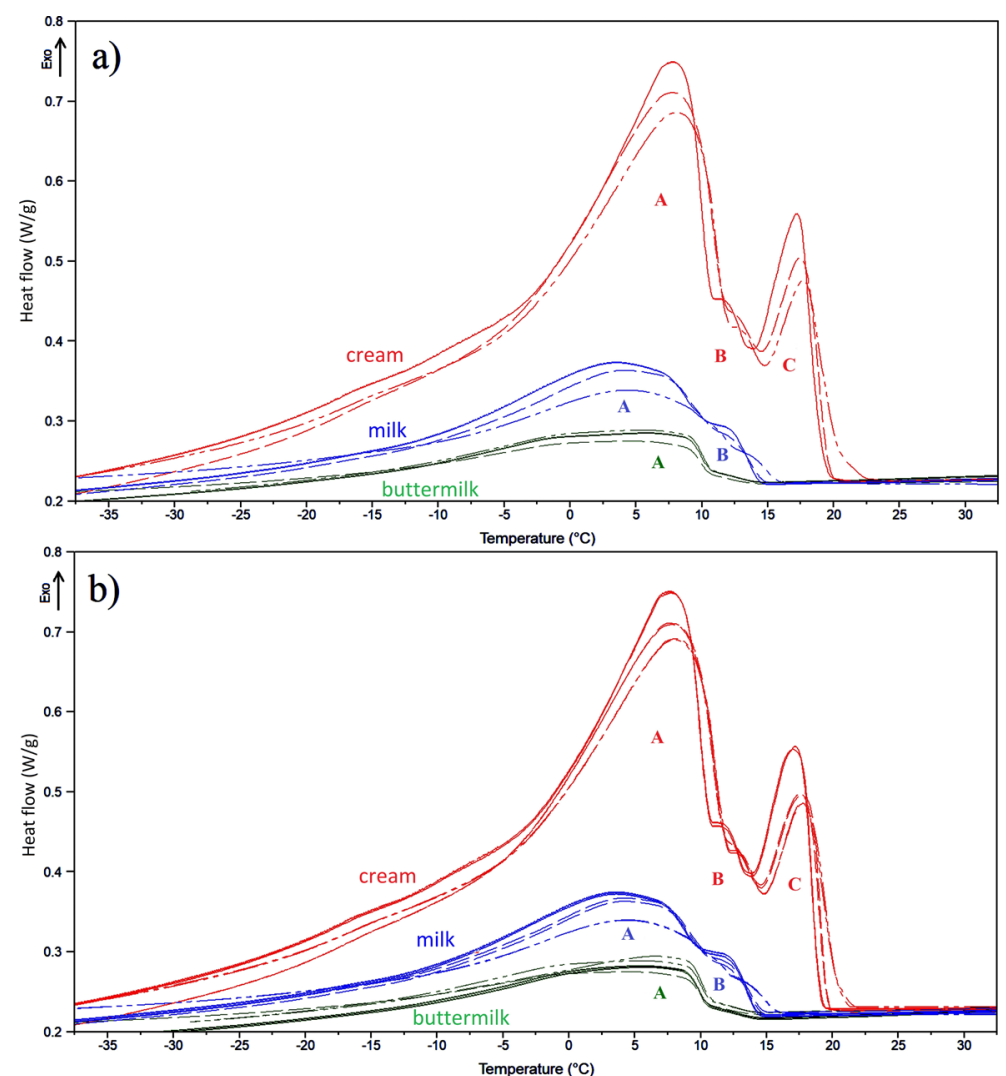

FIGURE 3. Exothermic peaks in differential scanning calorimetry (DSC) curves during freeze-dried milk, cream and buttermilk cooling in cycle I (a) and cycle II (b). Long-dash, short-dash and broken-dash lines represent replicate measurements in the same product. Different types of peaks are marked with letters A-C.
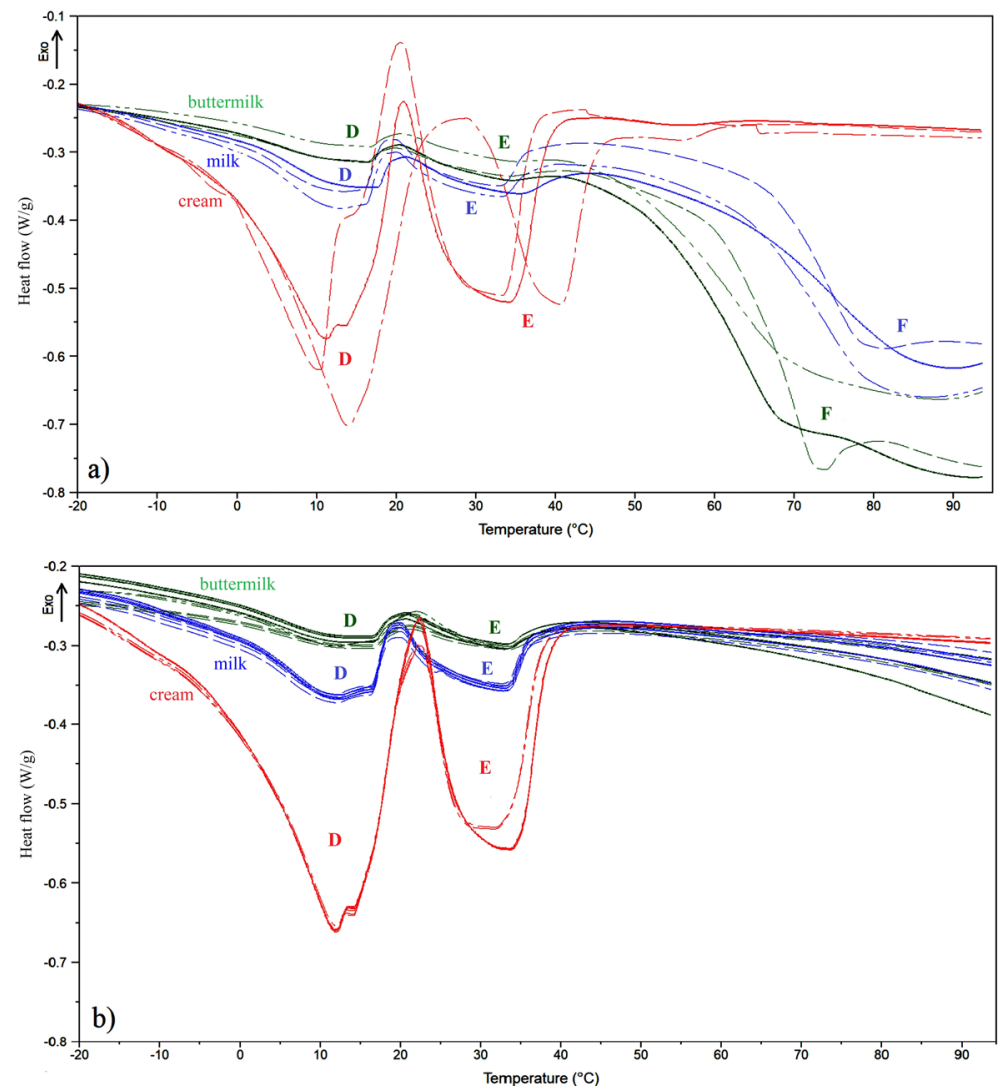

FIGURE 4. Endothermic peaks in differential scanning calorimetry (DSC) curves during freeze-dried milk, cream and buttermilk heating in cycle I (a) and cycle II (b). Long-dash, short-dash and broken-dash lines represent replicate measurements in the same product). Different types of peaks are marked with letters D-F. 
TABLE 4. Parameters of exothermic phase transition peaks of freeze-dried milk, cream and buttermilk in cycle I and cycle II of the differential scanning calorimetry (DSC) sequence.

\begin{tabular}{|c|c|c|c|c|c|c|c|c|c|}
\hline Peak & Cycle & Product & $\mathrm{T}_{\max }\left({ }^{\circ} \mathrm{C}\right)$ & $\mathrm{P}_{\text {height }}(\mathrm{W} / \mathrm{g})$ & $\Delta \mathrm{T}_{1 / 2}\left({ }^{\circ} \mathrm{C}\right)$ & $\mathrm{T}_{\text {onset }}\left({ }^{\circ} \mathrm{C}\right)$ & $\Delta \mathrm{H}(\mathrm{J} / \mathrm{g})$ & $\mathrm{P}_{\mathrm{s}}\left({ }^{\circ} \mathrm{C}\right)$ & $\mathrm{P}_{\mathrm{e}}\left({ }^{\circ} \mathrm{C}\right)$ \\
\hline \multirow{6}{*}{$\mathrm{A}^{1}$} & \multirow{3}{*}{1} & Milk & $3.95 \pm 0.44^{b}$ & $0.14 \pm 0.02^{\mathrm{b}}$ & $18.90 \pm 0.44^{b}$ & $14.46 \pm 0.14^{\mathrm{a}}$ & $18.19 \pm 2.50^{\mathrm{b}}$ & $16.36 \pm 0.84^{\mathrm{a}}$ & n.d.* \\
\hline & & Cream & $7.19 \pm 0.19^{\mathrm{a}}$ & $0.36 \pm 0.02^{\mathrm{a}}$ & $10.67 \pm 1.11^{\mathrm{c}}$ & $11.64 \pm 0.68^{\mathrm{b}}$ & $37.24 \pm 0.71^{\mathrm{a}}$ & $14.38 \pm 0.47^{\mathrm{b}}$ & n.d.* \\
\hline & & Buttermilk & $4.58 \pm 0.62^{\mathrm{b}}$ & $0.06 \pm 0.01^{\mathrm{c}}$ & $21.97 \pm 1.71^{\mathrm{aA}}$ & $11.47 \pm 0.88^{\mathrm{b}}$ & $8.93 \pm 0.98^{c}$ & $15.56 \pm 0.24^{\mathrm{a}}$ & n.d.* \\
\hline & \multirow{3}{*}{11} & Milk & $4.01 \pm 0.45^{\mathrm{c}}$ & $0.14 \pm 0.02^{\mathrm{b}}$ & $19.09 \pm 0.59^{b}$ & $14.81 \pm 0.65^{\mathrm{a}}$ & $18.49 \pm 2.23^{\mathrm{b}}$ & $16.33 \pm 0.69^{a}$ & n.d.* \\
\hline & & Cream & $7.30 \pm 0.37^{\mathrm{a}}$ & $0.36 \pm 0.02^{\mathrm{a}}$ & $10.65 \pm 0.97^{\mathrm{c}}$ & $11.64 \pm 0.65^{\mathrm{b}}$ & $34.21 \pm 4.49^{\mathrm{a}}$ & $14.33 \pm 0.45^{\mathrm{b}}$ & n.d.* \\
\hline & & Buttermilk & $4.69 \pm 0.36^{\mathrm{b}}$ & $0.06 \pm 0.01^{\mathrm{c}}$ & $19.88 \pm 0.33^{\text {ав }}$ & $10.94 \pm 0.07^{c}$ & $8.42 \pm 0.74^{c}$ & $15.48 \pm 0.20^{\mathrm{a}}$ & n.d.* \\
\hline \multirow{2}{*}{$\mathrm{C}$} & I & Cream & $17.79 \pm 0.30$ & $0.21 \pm 0.05$ & $2.76 \pm 0.05^{\mathrm{B}}$ & $19.64 \pm 0.66$ & $3.53 \pm 0.56$ & $21.96 \pm 1.64$ & $14.38 \pm 0.47$ \\
\hline & II & Cream & $17.99 \pm 0.33$ & $0.22 \pm 0.04$ & $3.01 \pm 0.09^{\mathrm{A}}$ & $19.50 \pm 0.53$ & $3.71 \pm 0.57$ & $20.79 \pm 1.11$ & $14.33 \pm 0.45$ \\
\hline
\end{tabular}

The presented values are means \pm standard deviations $(n=3)$. Values in columns, marked with lowercase letters $(\mathrm{a}-\mathrm{c})$ in the superscript differ significantly at $p \leq 0.05$; experimental factor - three products in the same cycle. Values in columns, marked with uppercase letters (A, B) in the superscript differ significantly at $p \leq 0.05$; experimental factor - two cycles in the same product. $\mathrm{T}_{\max }$ - peak temperature; $\mathrm{T}_{\text {onset }}$ - phase transition onset temperature; $\Delta \mathrm{T}_{1 / 2}$ - peak width at half height, $\Delta \mathrm{H}$ - enthalpy change; $\mathrm{P}_{\text {height }}$ - peak height at maximum; $\mathrm{P}_{\mathrm{s}}$ - peak onset temperature; $\mathrm{P}_{\mathrm{e}}-$ peak endset temperature. The peaks $\mathrm{A}$ and $\mathrm{C}$ are related to DSC curves in Figure 3.

${ }^{1}$ Undifferentiated peaks A and B (milk and cream) and peak A (buttermilk).

*no clear endset temperature.

Tomaszewska-Gras [2013] observed a peak corresponding to the overlap between LMPF and MMPF $\left(-30^{\circ} \mathrm{C}\right.$ to around $18^{\circ} \mathrm{C}$ ) and a clearly separated second peak corresponding to HMPF (from around $18^{\circ} \mathrm{C}$ to $35^{\circ} \mathrm{C}$ ) at the heating rate of $20^{\circ} \mathrm{C} / \mathrm{min}$. At the heating rate of $10^{\circ} \mathrm{C} / \mathrm{min}$, the peaks corresponding to LMPF and MMPF were clearly separated at a temperature of around $10^{\circ} \mathrm{C}$.

Milk and buttermilk samples were also characterised by endothermic peaks $\mathrm{F}$ which began to form at around $40^{\circ} \mathrm{C}$ and extended beyond the heating threshold of $95^{\circ} \mathrm{C}$ (Figure 4). However, these peaks were not fully formed within the temperature range set in the experiment, and their parameters were not determined. Peaks $\mathrm{F}$ were associated with irreversible reactions, which is why they were not noted in cycle II of the DSC sequence. The characteristics of peaks $\mathrm{F}$ differed in the DSC curves of the analysed products (buttermilk, milk) (Figure 4). Taller peaks were noted in buttermilk than in milk due to differences in the protein content of these products. Therefore, peaks $\mathrm{F}$ were probably related to protein transitions, including denaturation or evaporation of water. In the experiments conducted by Szulc et al. [2016] and Ostrowska-Ligęza et al. [2012], peaks associated with protein denaturation in milk powders occurred within a temperature range of around $40^{\circ} \mathrm{C}$ to nearly $140^{\circ} \mathrm{C}$, with a maximum at around $105^{\circ} \mathrm{C}$.

In both cycles of the DSC sequence, peaks A-E were tallest and most clearly differentiated in cream. The peaks in the DSC curves of milk were much smaller, and the smallest peaks were observed in buttermilk. Peaks became clearly separated, and the value of $\Delta \mathrm{H}$ and the absolute value of $\mathrm{P}_{\text {height }}$ increased with a rise in fat content (Table 4 and Table 5). These findings suggest that both exothermic and endothermic phase transitions promoted greater heat exchange in cream fat than in milk and buttermilk fat. The DSC curves (Figure 3 and Figure 4) and the chemical composition of milk, cream and buttermilk samples indicate that the presence of peaks in the analysed DSC sequence was influenced mainly by fat content. Higher fat content was also associated with a higher content of fatty acids in the examined samples (Table 3), and this factor played a role in the formation of peaks on DSC curves (Figure 3 and Figure 4). The effect of fat content on the DSC curves of milk, cream and buttermilk within the analysed temperature range was reported by Pugliese et al. [2019] who did not observe phase transition peaks in freeze-dried skim milk between $-50^{\circ} \mathrm{C}$ and $100^{\circ} \mathrm{C}$.

The parameters of phase transition peaks differed between milk, cream and buttermilk samples (Table 4 and Table 5). In most peaks, $\Delta \mathrm{T}_{1 / 2}$ values were lowest in cream relative to the remaining samples $(p \leq 0.05)$. The only exception was the value of $\Delta T_{1 / 2}$ in peak $\mathrm{D}$ in cycle $\mathrm{I}$, which did not differ significantly between cream and the remaining products $(p>0.05)$. The lowest value of $\Delta \mathrm{T}_{1 / 2}$ was noted in cycle II of the endothermic phase transition of cream $(p \leq 0.05)$ (Table 5). The values of $\Delta \mathrm{T}_{1 / 2}$ indicate that cream was characterised by the highest rates of crystallisation and melting. Exothermic peaks A and B in the DSC curves of cream were analysed jointly, and they were characterised by the highest maximum phase transition temperature $(p \leq 0.05)$. In milk and buttermilk samples, $T_{\max }$ values were lower and did not differ significantly in cycle I $(p>0.05)$, but differed in cycle II $(p \leq 0.05)$ (Table 4). In cycle II, $\mathrm{T}_{\max }$ was lowest in peak $\mathrm{D}$ in the DSC curve of cream $(p \leq 0.05)$. The $\mathrm{T}_{\max }$ value of peak $\mathrm{E}$ did not differ between the examined products $(p>0.05)$ (Table 5). The highest value of $T_{\text {onset }}$ denoting the beginning of a given phase transition was observed in exothermic peak A of milk in cycles I and II $(p \leq 0.05)$ (Table 4) and in endothermic peak D of milk in cycle II $(p \leq 0.05)$ (Table 5). The $\mathrm{T}_{\text {onset }}$ value of peak $\mathrm{E}$ was highest in cream $(p \leq 0.05)$ (Table 5). An analysis of the overlap between peaks A and B in cycles I and II revealed the highest value of $\mathrm{P}_{\mathrm{s}}$ in milk $(p \leq 0.05)$ (Table 4), whereas in endothermic peaks in cycle II, the value of $P_{s}$ was highest in cream $(p \leq 0.05)$ (Table 5). The values 
TABLE 5. Parameters of endothermic phase transition peaks of freeze-dried milk, cream and buttermilk in cycle I and cycle II of the differential scanning calorimetry (DSC) sequence.

\begin{tabular}{|c|c|c|c|c|c|c|c|c|c|}
\hline Peak & Cycle & Product & $\mathrm{T}_{\max }\left({ }^{\circ} \mathrm{C}\right)$ & $\mathrm{P}_{\text {height }}(\mathrm{W} / \mathrm{g})$ & $\Delta \mathrm{T}_{1 / 2}\left({ }^{\circ} \mathrm{C}\right)$ & $\mathrm{T}_{\text {onset }}\left({ }^{\circ} \mathrm{C}\right)$ & $\Delta \mathrm{H}(\mathrm{J} / \mathrm{g})$ & $\mathrm{P}_{\mathrm{s}}\left({ }^{\circ} \mathrm{C}\right)$ & $\mathrm{P}_{\mathrm{e}}\left({ }^{\circ} \mathrm{C}\right)$ \\
\hline \multirow{6}{*}{ D } & \multirow{3}{*}{ I } & Milk & $12.94 \pm 0.47^{\mathrm{A}}$ & $-0.08 \pm 0.02^{b}$ & $13.70 \pm 0.44^{\mathrm{B}}$ & $-1.88 \pm 1.07$ & $7.51 \pm 1.93^{b}$ & n.d. ${ }^{*}$ & $20.16 \pm 0.90$ \\
\hline & & Cream & $11.85 \pm 1.79$ & $-0.42 \pm 0.06^{\mathrm{a}}$ & $14.76 \pm 1.28$ & $-4.33 \pm 2.41$ & $42.03 \pm 4.19^{\mathrm{a}}$ & n.d.* & $23.36 \pm 4.54$ \\
\hline & & Buttermilk & $11.73 \pm 0.24$ & $-0.03 \pm 0.00^{c}$ & $14.55 \pm 0.45^{\text {в }}$ & $-2.93 \pm 0.87^{\mathrm{A}}$ & $2.78 \pm 0.54^{\mathrm{cB}}$ & n.d.* & $20.22 \pm 0.33^{\mathrm{B}}$ \\
\hline & \multirow{3}{*}{ II } & Milk & $12.09 \pm 0.30^{\mathrm{aB}}$ & $-0.09 \pm 0.02^{\mathrm{b}}$ & $14.63 \pm 0.26^{\mathrm{abA}}$ & $-2.90 \pm 1.02^{\mathrm{a}}$ & $8.64 \pm 1.76^{\mathrm{b}}$ & n.d.* & $20.21 \pm 0.64^{c}$ \\
\hline & & Cream & $11.62 \pm 0.49^{\mathrm{b}}$ & $-0.40 \pm 0.03^{c}$ & $13.61 \pm 1.11^{\mathrm{b}}$ & $-3.80 \pm 0.88^{\mathrm{b}}$ & $38.84 \pm 1.88^{\mathrm{a}}$ & n.d.* & $22.58 \pm 0.36^{\mathrm{a}}$ \\
\hline & & Buttermilk & $12.07 \pm 0.37^{\mathrm{a}}$ & $-0.04 \pm 0.01^{\mathrm{a}}$ & $15.51 \pm 0.29^{\mathrm{aA}}$ & $-4.35 \pm 0.64^{\mathrm{bB}}$ & $3.81 \pm 0.72^{\mathrm{cA}}$ & n.d.* & $21.19 \pm 0.44^{\mathrm{bA}}$ \\
\hline \multirow{6}{*}{ E } & \multirow{4}{*}{ I } & Milk & $33.46 \pm 1.20$ & $-0.05 \pm 0.01^{\mathrm{b}}$ & $12.66 \pm 0.71^{\mathrm{A}}$ & $20.97 \pm 0.97$ & $3.86 \pm 0.77^{\mathrm{b}}$ & $20.26 \pm 0.83$ & $42.79 \pm 2.04^{\mathrm{B}}$ \\
\hline & & Cream & $34.37 \pm 5.58$ & $-0.29 \pm 0.04^{c}$ & $11.34 \pm 2.45$ & $24.73 \pm 5.80$ & $19.63 \pm 5.08^{\mathrm{a}}$ & $23.36 \pm 4.54$ & $45.17 \pm 4.12$ \\
\hline & & Buttermilk & $32.50 \pm 0.26$ & $-0.02 \pm 0.00^{\mathrm{aA}}$ & $12.69 \pm 0.36^{\mathrm{A}}$ & $21.61 \pm 0.48$ & $1.26 \pm 0.28^{\mathrm{cB}}$ & $20.25 \pm 0.29^{\mathrm{B}}$ & $40.05 \pm 0.87^{\mathrm{B}}$ \\
\hline & & Milk & $33.36 \pm 0.87$ & $-0.07 \pm 0.01^{\mathrm{b}}$ & $11.73 \pm 0.30^{\mathrm{aB}}$ & $20.88 \pm 0.70^{c}$ & $4.68 \pm 0.89^{\mathrm{b}}$ & $20.22 \pm 0.74^{c}$ & $45.58 \pm 0.60^{\mathrm{aA}}$ \\
\hline & \multirow[t]{2}{*}{ II } & Cream & $32.74 \pm 0.68$ & $-0.28 \pm 0.02^{c}$ & $10.69 \pm 1.09^{\mathrm{b}}$ & $23.32 \pm 0.45^{\mathrm{a}}$ & $17.31 \pm 2.02^{\mathrm{a}}$ & $22.62 \pm 0.46^{\mathrm{a}}$ & $43.66 \pm 0.39^{b}$ \\
\hline & & Buttermilk & $32.96 \pm 0.43$ & $-0.03 \pm 0.00^{a \mathrm{~B}}$ & $10.98 \pm 0.14^{\text {БВ }}$ & $21.85 \pm 0.41^{\mathrm{b}}$ & $1.88 \pm 0.28^{\mathrm{cA}}$ & $21.23 \pm 0.40^{\mathrm{bA}}$ & $42.64 \pm 0.37^{\mathrm{cA}}$ \\
\hline
\end{tabular}

The presented values are means \pm standard deviations $(n=3)$. Values in columns, marked with lowercase letters $(a-c)$ in the superscript differ significantly at $p \leq 0.05$; experimental factor - three products in the same cycle. Values in columns, marked with uppercase letters (A, B) in the superscript differ significantly at $p \leq 0.05$; experimental factor - two cycles in the same product. $\mathrm{T}_{\max }$ - peak temperature; $\mathrm{T}_{\text {onset }}-$ phase transition onset temperature; $\Delta \mathrm{T}_{1 / 2}$ - peak width at half height, $\Delta \mathrm{H}$ - enthalpy change; $\mathrm{P}_{\text {height }}$ - peak height at maximum; $\mathrm{P}_{\mathrm{s}}-$ peak onset temperature; $\mathrm{P}_{\mathrm{e}}-$ peak endset temperature. The peaks D and $\mathrm{E}$ are related to DSC curves in Figure 4.

*no clear onset temperature.

of $\mathrm{P}_{\mathrm{e}}$ differed significantly between the samples $(p \leq 0.05)$ only in endothermic peaks $\mathrm{D}$ and $\mathrm{E}$ in cycle II (Table 5).

The DSC sequence was divided into two cycles to analyse the impact of thermal history on the characteristics of DSC curves and the parameters of phase transition peaks in milk, buttermilk and cream samples. A comparison of cycle I and cycle II revealed minor differences in the exothermic crystallisation peaks of milk fat (Figure 3). Significant differences $(p \leq 0.05)$ in $\Delta \mathrm{T}_{1 / 2}$ values were found between peak A of buttermilk and peak $C$ of cream (Table 4), which suggests that buttermilk fat was crystallised more rapidly, whereas cream fat was crystallised at a slower rate in cycle II. An analysis of endothermic peaks revealed greater differences in curve characteristics and the parameters of phase transition peaks between cycle I and cycle II (Figure 4, Table 5). The most notable difference was the absence of peaks $\mathrm{F}$ in milk and buttermilk samples in cycle II, which are probably associated with irreversible phase transitions of proteins in cycle I. Only endothermic peaks relating to reversible fat melting reactions were noted in cycle II. Significant differences $(p \leq 0.05)$ in the parameters of melting peaks were observed between cycle I and cycle II, including in the values of $\mathrm{T}_{\text {max }}$ in peak $\mathrm{D}$, $\Delta \mathrm{T}_{1 / 2}$ and $\Delta \mathrm{H}$ in peaks $\mathrm{D}$ and $\mathrm{E}, \mathrm{P}_{\mathrm{e}}$ in peak $\mathrm{E}$ in milk samples, $\mathrm{T}_{\text {onset }}$ and $\mathrm{P}_{\mathrm{e}}$ in peak $\mathrm{D}, \Delta \mathrm{T}_{1 / 2}$ and $\Delta \mathrm{H}$ in peaks $\mathrm{D}$ and $\mathrm{E}$, and $\mathrm{P}_{\mathrm{s}}$ and $P_{e}$ in peak $E$ in buttermilk samples (Table 5). The remaining parameters of exothermic and endothermic processes did not differ significantly $(p>0.05)$ between cycle I and cycle II (Table 4 and Table 5). In repeated analyses of the same product, greater differences in peak parameters (higher standard deviation) and curve characteristics were observed in cycle I than in cycle II, in particular in endothermic peaks in cream
(Table 5, Figure 4). In endothermic peaks, significant differences $(p \leq 0.05)$ in the values of $\Delta \mathrm{T}_{12}, \mathrm{P}_{\mathrm{s}}$ and $\mathrm{P}_{\mathrm{e}}$ were determined only in cycle II (Table 5). The differences between DSC cycles indicate that the thermal history of the examined samples influenced curve characteristics, crystallisation rate, onset temperature, melting rate and changes in melting enthalpy. Other authors also observed that thermal history affects the shape of the DSC curves, the parameters of crystallisation and melting of milk fat, as well as microcrystal structure and nucleation rate which determine crystal polymorphism and size [Lopez et al., 2007; ten Grotenhuis, 1999; Tomaszewska-Gras, 2013]. Changes in temperature promote the conversion of unstable polymorphic $\alpha$ forms of milk fat crystals into stable $\beta$ and $\beta$, forms due to thermal memory effects [Wiking et al., 2009]. These factors were probably responsible for the differences between cycle I and cycle II of the analysed DSC sequence, in particular in melting parameters, as well as the similarities in DSC curves representing repeated heating and cooling stages in cycle II (Figure 4).

\section{CONCLUSIONS}

The research results provide a comprehensive overview of the properties of the milk, cream and sweet buttermilk emulsion phase. The fat globules were largest in cream and smallest in buttermilk. The microscopic analysis revealed the presence of fat globule agglomerates in cream and chains of small fat globules in buttermilk. The size of fat globules was related with the fatty acid content of the examined products. The proportion of LCFAs was highest in cream and lowest in milk, whereas the reverse was noted in an 
analysis of MCFAs. The content of monoenoic and polyenoic fatty acids was highest in buttermilk and lowest in milk, and it was related with the content of fat globule membrane components. The analysed products differed in the shape of DSC curves and the parameters of phase transition peaks. Unlike milk and buttermilk, cream was characterised by an additional peak on the DSC curve, as well as much higher values of crystallisation and greater changes in melting enthalpy. These differences were probably induced by fat content which was related with the fatty acid composition of each product. The study demonstrated that parameters $\mathrm{T}_{\max }, \mathrm{P}_{\text {height }}$ and $\Delta \mathrm{T}_{1 / 2}$ of exothermic crystallisation peaks and parameters $\mathrm{P}_{\text {height }}, \Delta \mathrm{T}_{1 / 2}$ and $\Delta \mathrm{H}$ of endothermic melting peaks were reliable indicators for comparing the thermal properties of milk, cream and buttermilk. The thermal history of the examined products, which was shaped during repeated heating and cooling stages within a temperature range of $-40^{\circ} \mathrm{C}$ to $95^{\circ} \mathrm{C}$, influenced the crystallisation and melting characteristics of milk, cream and buttermilk fat. The thermal phase transitions should be characterised in greater detail and linked with the fatty acid profile and the size of milk fat globules, which may be used to optimise the production and storage processes of dairy products and to improve and control their quality. Milk, buttermilk and cream should also be compared in terms of the contents of components other than milk fat.

\section{ACKNOWLEDGEMENTS}

The authors would like to thank Justyna Ziajka and Waldemar Brandt for technical assistance during the study.

\section{RESEARCH FUNDING}

Project financially supported by the Minister of Education and Science under the program entitled "Regional Initiative of Excellence" for the years 2019-2022, Project No. 010/ RID/2018/19, amount of funding 12.000.000 PLN.

\section{CONFLICT OF INTERESTS}

Authors declare no conflict of interests.

\section{ORCID IDs}

K. Bohdziewicz https://orcid.org/0000-0003-2394-0495

O. Brożek https://orcid.org/0000-0002-0133-3224

K. Kiełczewska https://orcid.org/0000-0002-5267-925X

\section{REFERENCES}

1. AOAC. 2007. Official Methods of Analysis of AOAC International. 18th ed. Gaithersburg, MD, AOAC International.

2. Berton, A., Rouvellac, S., Robert, B., Rousseau, F., Lopez, C., Crenon, I. (2012). Effect of the size and interface composition of milk fat globules on their in vitro digestion by the human pancreatic lipase: Native versus homogenized milk fat globules. Food Hydrocolloids, 29(1), 123-134.

https://doi.org/10.1016/j.foodhyd.2012.02.016
3. Briard, V., Leconte, N., Michel, F., Michalski, M.-C. (2003). The fatty acid composition of small and large naturally occurring milk fat globules. European Journal of Lipid Science and Technology, 105(11), 677-682.

https://doi.org/10.1002/ejlt.200300812

4. Bugeat, S., Briard-Bion, V., Pérez, J., Pradel, P., Martin, B., Lesieur, S., Lopez, C. (2011). Enrichment in unsaturated fatty acids and emulsion droplet size affect the crystallization behaviour of milk triacylglycerols upon storage at $4^{\circ} \mathrm{C}$. Food Research International, 44(5), 1314-1330.

https://doi.org/10.1016/j.foodres.2011.01.003

5. Conway, V., Gauthier, S.F., Pouliot, Y. (2014). Buttermilk: Much more than a source of milk phospholipids. Animal Frontiers, 4(2), $44-51$.

\section{https://doi.org/10.2527/af.2014-0014}

6. Dewettinck, K., Rombaut, R., Thienpont, N., Le, T.T., Messens, K., Van Camp, J. (2008). Nutritional and technological aspects of milk fat globule membrane material. International Dairy Journal, 18, 436-457.

https://doi.org/10.1016/j.idairyj.2007.10.014

7. Dhungana, P., Truong, T., Palmer, M., Bansal, N., Bhandari, B. (2017). Size-based fractionation of native milk fat globules by two-stage centrifugal separation. Innovative Food Science \& Emerging Technologies, 41, 235-243. https://doi.org/10.1016/j.ifset.2017.03.011

8. El-Loly, M.M. (2011). Composition, properties and nutritional aspects of milk fat globule membrane: a review. Polish Journal of Food and Nutrition Sciences, 61 (1), 7-32.

https://doi.org/10.2478/v10222-011-0001-0

9. Fauquant, C., Briard, V., Leconte, N., Michalski, C. (2005). Differently sized native milk fat globules separated by microfiltration: fatty acid composition of the milk fat globule membrane and triglyceride core. European Journal of Lipid Science and Technology, 107(2), 80-86.

https://doi.org/10.1002/ejlt.200401063

10. Garczewska-Murzyn, A., Smoczyński, M., Kotowska, N., Kiełczewska K. (2021). Effect of buttermilk and skimmed milk powder on the properties of low-fat yoghurt. Journal of Food Science and Technology.

https://doi.org/10.1007/s13197-021-05227-w

11. Gassi, J.Y., Blot, M., Beaucher, E., Robert, B., Leconte, N., Camier, B., Rousseau, F., Bourlieu, C., Jardin, J., Briard-Bion, V., Lambert, S., Gesan-Guiziou, G., Lopez, C., Gaucheron, F. (2016). Preparation and characterisation of a milk polar lipids enriched ingredient from fresh industrial liquid butter serum: Combination of physico-chemical modifications and technological treatments. International Dairy Journal, 52, 26-34. https://doi.org/10.1016/j.idairyj.2015.08.012

12. Hickey, C.D., Diehl, B.W.K., Nuzzo, M., Millqvist-Feurby, A., Wilkinson, M.G., Sheehan, J.J. (2017). Influence of buttermilk powder or buttermilk addition on phospholipid content, chemical and bio-chemical composition and bacterial viability in Cheddar style-cheese. Food Research International, 102, 748-758.

https://doi.org/10.1016/j.foodres.2017.09.067

13. Hokkanen, S.P., Partanen, R., Jukkola, A., Frey, A.D., Rojas, O.J. (2021). Partitioning of the milk fat globule membrane between buttermilk and butter serum is determined by the thermal behaviour of the fat globules. International Dairy Journal, 112, art. no. 104863. https://doi.org/10.1016/j.idairyj.2020.104863 
14. ISO (2002). Milk fat - Preparation of fatty acid methyl esters. ISO standard 15884/IDF 182:2002.

15. ISO (2010). Milk - Determination of fat content - Gravimetric method (Reference method). ISO standard 1211/IDF 1:2010.

16. ISO (2018). Cream - Determination of fat content - Acido-butyrometric (Gerber method). ISO standard 19660/IDF 237:2018.

17. ISO (2018). Milk - Determination of fat content - Acido-butyrometric (Gerber method). ISO standard 19662/IDF 238:2018.

18. Jensen, R.G. (2002). The composition of bovine milk lipids: January 1995 to December 2000. Journal of Dairy Science, 85(2), 295-350.

https://doi.org/10.3168/jds.S0022-0302(02)74079-4

19. Jhanwar, A., Ward, R.E. (2014). Particle size distribution and lipid composition of skim milk lipid material. International Dairy Journal, 36(2), 110-117. https://doi.org/10.1016/j.idairyj.2014.01.010

20. Jukkola, A., Rojas, O.J. (2017). Milk fat globules and associated membranes: Colloidal properties and processing effects. Advances in Colloid and Interface Science, 245, 92-101. https://doi.org/10.1016/j.cis.2017.04.010

21. Lambert, S., Leconte, N., Blot, M., Rousseau, F., Robert, B., Camier, B., Gassi, J-Y., Cauty, C., Lopez, Ch., Gésan-Guiziou, G. (2016). The lipid content and microstructure of industrial whole buttermilk and butter serum affect the efficiency of skimming. Food Research International, 83, 121-130.

https://doi.org/10.1016/j.foodres.2016.03.002

22. Lopez, C., Bourgaux, C., Lesieur, P., Ollivon, M. (2007). Coupling of time-resolved synchrotron X-ray diffraction and DSC to elucidate the crystallisation properties and polymorphism of triglycerides in milk fat globules. Le Lait, 87(4-5), 459-480.

https://doi.org/10.1051/lait:2007018

23. Lopez, C., Cauty, C., Guyomarc'h, F. (2015). Organization of lipids in milks, infant milk formulas and various dairy products: role of technological processes and potential impacts. Dairy Science \& Technology, 95(6), 863-893.

https://doi.org/10.1007/s13594-015-0263-0

24. Lopez, C., Lesieur, P., Bourgaux, C., Keller, G., Ollivon, M. (2001). Thermal and structural behavior of milk fat: 2. Crystalline forms obtained by slow cooling of cream. Journal of Colloid and Interface Science, 240(1), 150-161. https://doi.org/10.1006/jcis.2001.7664

25. Michalski, M.-C., Leconte, N., Briard-Bion, V., Fauquant, J., Maubois, J., Goudédranche, H. (2006). Microfiltration of raw whole milk to select fractions with different fat globule size distributions: Process optimization and analysis. Journal of Dairy Science, 89(10), 3778-3790.

https://doi.org/10.3168/jds.S0022-0302(06)72419-5

26. Michalski, M.-C., Ollivon, M., Briard, V., Leconte, N., Lopez, C. (2004). Native fat globules of different sizes selected from raw milk: thermal and structural behavior. Chemistry and Physics of Lipids, 132(2), 247-261.

https://doi.org/10.1016/j.chemphyslip.2004.08.007
27. Ostrowska-Ligęza, E., Górska, A., Wirkowska, M., Koczoń, P. (2012). An assessment of various powdered baby formulas by conventional methods (DSC) or FT-IR spectroscopy. Journal of Thermal Analysis and Calorimetry, 110(1), 465-471.

https://doi.org/10.1007/s10973-011-2158-5

28. Pugliese, A., Paciulli, M., Chiavaro, E., Mucchetti, G. (2019). Application of differential scanning calorimetry to freeze-dried milk and milk fractions. Journal of Thermal Analysis and Calorimetry, 137(2), 703-709. https://doi.org/10.1007/s10973-018-7971-7

29. Sanchez-Juanes, F., Alonso, J.M., Zancada, L., Hueso, P. (2009). Distribution and fatty acid content of phospholipids from bovine milk and bovine milk fat globule membranes. International Dairy Journal, 19(5), 273-278.

https://doi.org/10.1016/j.idairyj.2008.11.006

30. Singh, H. (2006). The milk fat globule membrane - A biophysical system for food applications. Current Opinion in Colloid and Interface Science, 11(2-3), 154-163. https://doi.org/10.1016/j.cocis.2005.11.002

31. Singh, H., Gallier, S. (2017). Nature's complex emulsion: The fat globules of milk. Food Hydrocolloids, 68, 81-89.

https://doi.org/10.1016/j.foodhyd.2016.10.011

32. Smoczyński, M., Staniewski, B., Kiełczewska, K. (2012). Composition and structure of the bovine milk fat globule membrane some nutritional and technological implications. Food Review International, 28(2), 188-202. https://doi.org/10.1080/87559129.2011.595024

33. Szulc, K., Nazarko, J., Ostrowska-Ligęza, E., Lenart, A. (2016). Effect of fat replacement on flow and thermal properties of dairy powders. LWT - Food Science and Technology, 68, 653-658. https://doi.org/10.1016/j.Iwt.2015.12.060

34. ten Grotenhuis, E., van Aken, G.A., van Malssen, K.F., Schenk, H. (1999). Polymorphism of milk fat studied by differential scanning calorimetry and real-time X-ray powder diffraction. Journal of the American Oil Chemists' Society, 76(9), 1031-1039. https://doi.org/10.1007/s11746-999-0201-5

35. Tomaszewska-Gras, J. (2013) Melting and crystallization DSC profiles of milk fat depending on selected factors. Journal of Thermal Analysis and Calorimetry, 113(1), 199-208. https://doi.org/10.1007/s10973-013-3087-2

36. Truong, T., Bansal, N., Sharma, R., Palmer, M., Bhandari, B. (2014). Effects of emulsion droplet sizes on the crystallisation of milk fat. Food Chemistry, 145, 725-735. https://doi.org/10.1016/j.foodchem.2013.08.072

37. Vanderghem, C., Bodson, P., Danthine, S., Paquot, M., Deroanne, C., Blecker, C. (2010). Milk fat globule membrane and buttermilks: from composition to valorization. Biotechnology, Agronomy, Society and Environment, 14(3), 485-500.

38. Wiking, L., De Graef, V., Rasmussen, M., Dewettinck, K. (2009). Relations between crystallisation mechanisms and microstructure of milk fat. International Dairy Journal, 19(8), 424-430. https://doi.org/10.1016/j.idairyj.2009.03.003 
